Abstracta Iranica Abstracta Iranica

Revue bibliographique pour le domaine irano-aryen

Volume 23 | 2002

Comptes rendus des publications de $\mathbf{2 0 0 0}$

\title{
Dīvān. Éd., introd. Omīd Eslām-panāh, Tehrān, Markaz-e Našr-e Mīrāt-e Maktūb, 1379/2000, 463 p. [Zabān va adabiyyāt-e fārsī, 22].
}

Ève Feuillebois-Piérunek

\section{(2) OpenEdition}

Journals

Édition électronique

URL : http://journals.openedition.org/abstractairanica/35793

DOI : 10.4000/abstractairanica.35793

ISSN : 1961-960X

Éditeur :

CNRS (UMR 7528 Mondes iraniens et indiens), Éditions de l'IFRI

Édition imprimée

Date de publication : 15 mai 2002

ISSN : 0240-8910

Référence électronique

Ėve Feuillebois-Piérunek, « Dīvān. Éd., introd. Omīd Eslām-panāh, Tehrān, Markaz-e Našr-e Mīrāț-e Maktūb, 1379/2000, 463 p. [Zabān va adabiyyāt-e fārsī, 22]. », Abstracta Iranica [En ligne], Volume 23 | 2002, document 263, mis en ligne le 08 février 2010, consulté le 25 septembre 2020. URL : http:// journals.openedition.org/abstractairanica/35793; DOI : https://doi.org/10.4000/abstractairanica. 35793

Ce document a été généré automatiquement le 25 septembre 2020.

Tous droits réservés 


\title{
Dīvān. Éd., introd. Omīd Eslām- panāh, Tehrān, Markaz-e Našr-e Mīrāte Maktūb, 1379/2000, 463 p. [Zabān va adabiyyāt-e fārsī, 22].
}

\author{
Ève Feuillebois-Piérunek
}

1 Mīrzā Aḥmad Kermānšāhī (1848-1907), surnommé Ferdowsī Ḥoseynī ou Elhāmī était originaire de Tūyserkān dans la région d'Ispahan, mais il s'installa et vécut à Kermānšāh. La légende pieuse veut qu'il n'ait rien connu à l'art poétique et qu'il ait mené une vie simple et laborieuse jusqu'à ce que l'Imām Hoseyn lui apparaisse et lui demande de composer des poèmes sur les événements de Kerbela. Il fut alors gratifié de dons poétiques et ses poèmes furent rassemblés en un matnavi épico-religieux, Bāg-e Ferdows, composé d'après le mètre du Šāh-nāme et divisé en 4 parties. Outre le texte principal, nous trouvons dans ce livre des ǵazal-s, des qașide-s et deux courts matnavii-s intitulés Ḥusn-e manzar et Bustān-e mātam.

2 Les textes sont édités de façon critique à partir d'une édition lithographique de 1327 et de 4 manuscrits iraniens. Lexique des mots difficiles et expressions, index, bibliographie.

3 Une introduction sommaire sur la vie, l'œuvre et le style de l'auteur, qui est en fait une mosaïque de citations d'autres auteurs (notamment Șafā'), sans réflexion personnelle ni analyse. 
INDEX

Thèmes : 11.1.1. Littérature persane classique

\section{AUTEURS}

ÈVE FEUILLEBOIS-PIÉRUNEK

Sorbonne Nouvelle - Paris III 